\title{
AN ATTEMPT TO INCREASE RESISTANCE TO PERTUSSIS IN NEWBORN INFANTS BY IMMUNIZING THEIR MOTHERS DURING PREGNANCY ${ }^{1}$
}

\author{
By JOHN A. LICHTY, JR., BETTY SLAVIN 2 AND WILLIAM L. BRADFORD \\ (From the Departments of Pediatrics and Bacteriology, University of Rochester School of \\ Medicine and Dentistry and the Strong Memorial and Rochester Municipal Hospitals. \\ Rochester, New York)
}

(Received for publication April 22, 1938)

It is rather generally accepted that many infants in the first half-year of life are not susceptible to some of the common infectious diseases, such as diphtheria, poliomyelitis, scarlet fever, or measles (1). This resistance is particularly striking in the infant whose mother is known to have had the disease in question. Numerous investigators have shown by experimental work, in human beings as well as in animals, that this immunity coincides with the presence of specific antibodies which have been passively transferred from the mother to the offspring. No attempt is made to give a complete review of this subject for it is surveyed in the publications of Ratner et al. (2) and Aycock and Kramer (3). In man, the transfer of antibody probably occurs chiefly by way of the placenta.

The incidence of pertussis is high in newborn inifants. Pfaundler and Schlossmann (4) give mortality rates between 26 and 55 per cent during the first year of life, and Griffith and Mitchell (5) state "the danger being greater the younger the child."

Within recent years numerous attempts have been made to immunize children actively against this disease. It is not within the scope of this paper to discuss the efficacy of this procedure or the various techniques employed, but it may be stated safely that most advocates of active immunization recommend that it be carried out during the second half-year of life. This period coincides with that used for other types of active immunization, because it is believed that very young infants do not respond to antigenic stimuli

1 This investigation was aided, in part, by a grant from the Committee on Therapeutic Research, Council on Pharmacy and Chemistry, American Medical Association.

2 Working under a grant from the Fluid Research Fund of the University of Rochester. in any degree comparable to that of older individuals. In the case of pertussis, unfortunately, this plan of active immunization leaves the child unprotected during that period of life when the mortality is highest.

In view of the above facts it seemed worth while to immunize women during pregnancy with a vaccine prepared with Hemophilus pertussis, in the hope that antibodies so produced might be transferred to the fetus. The experiment was suggested further by the reports which follow.

Burckhardt (6) found that infants born of mothers who had received Jennerian vaccination during pregnancy were refractive to vaccine virus during the first days of life, while Polano (7) demonstrated the transfer of tetanus antitoxin from mother to infant. Bennholdt-Thomsen (8) showed that, in rabbits, immunization during pregnancy with $H$. pertussis vaccine resulted in a passive transfer of complement-fixing antibodies to the offspring. He concluded further that this transfer takes place particularly during the latter part of pregnancy, but not during nursing. He was unable to immunize young rabbits actively until they reached the age of five weeks. No reference has been noted of an attempt to apply this finding to human beings, but Weichsel and Douglas (9), using the complement-fixation test, and Bradford and Slavin (10), using the opsonocytophagic test, have demonstrated a suggestive correlation between the level of $H$. pertussis antibodies in the blood of mother and infant. Furthermore, Bradford (11) has reported a prophylactic effect from giving the blood of an individual convalescent from pertussis to a child recently exposed to the disease. He regards this effect as being due to the establishment of a passive immunity analogous to that produced by the placental transfer of antibodies. 


\section{PROCEDURE}

During 1936 and 1937, patients in the Obstetrical Outpatient Department of the Strong Memorial and Rochester Municipal Hospitals were selected for immunization. Only healthy individuals, who were considered to have normal pregnancies, were included. Aside from this, the women were selected at random. Careful inquiry was made regarding the history of pertussis, and several patients were excluded later because their replies were uncertain.

In view of the reports of Rodolfo (12) and of Bennholdt-Thomsen (8) it was decided to attempt active immunization of these prospective mothers during the last six weeks of pregnancy. The antigen was a commercial ${ }^{8}$ vaccine prepared from $H$. pertussis organisms in Phase I, according to the method of Sauer (13). Wherever possible, three parenteral injections of the vaccine were administered at two-week intervals during the last six weeks of pregnancy. The initial dose was $0.5 \mathrm{cc}$., given subcutaneously or intramuscularly into the upper arm. Intramuscular and subcutaneous injections were used with about equal frequency, but no conclusion was drawn as to which was the less painful. The remaining doses varied from 0.5 to $1.0 \mathrm{cc}$. depending on the reaction produced by the previous dose. Many of the women complained of a sore arm following the injection, but in most instances this did not interfere with sleep or work. When it did, the subsequent dose was not increased. Of 42 patients receiving the vaccine in this manner, only 4 refused the third injection, and only 1 of this group reported a systemic reaction (nausea and vomiting).

The opsono-cytophagic reaction of the blood for $H$. pertussis was the procedure used throughout this work to obtain a measure of the effect of immunization in both mother and newborn. This technique, originally devised by Huddleson, Johnson, and Hamann (14) for studies of brucellosis, has been slightly modified by Bradford and Slavin (10) for work with pertussis. For the details of the modified method, their paper should be consulted. Briefly, it is as follows: A standard number of dead pertussis bacilli in the virulent

8 The Eli Lilly and Company kindly supplied the vaccine used in this work.
(Phase I) form are mixed with the heparinized blood of the patient to be tested. The degree of phagocytosis is determined after incubation at $37^{\circ} \mathrm{C}$. for 30 minutes by counting the number of bacilli in each of 25 leukocytes. The 25 leukocytes are then arranged in one or more of 3 possible groups depending on the number of organisms each contains (Table I). We found

TABLE I

The opsono-cytophagic reaction of the blood of mothers and newborns when the mothers had no history of pertussis and no immuniration during pregnancy

\begin{tabular}{|c|c|c|c|c|c|c|}
\hline \multirow{3}{*}{ Family name } & \multicolumn{3}{|c|}{ Mothers } & \multicolumn{3}{|c|}{ Newborns } \\
\hline & \multicolumn{3}{|c|}{$\begin{array}{l}\text { Distribution of cells ac- } \\
\text { cording to number of } \\
\text { organisms phagocytosed }\end{array}$} & \multicolumn{3}{|c|}{$\begin{array}{l}\text { Distribution of cells ac- } \\
\text { cording to number of } \\
\text { organisms phagocytosed }\end{array}$} \\
\hline & $\begin{array}{l}0 \text { to } 4 \\
\text { organ- } \\
\text { isms }\end{array}$ & $\begin{array}{l}5 \text { to } 19 \\
\text { organ- } \\
\text { isms }\end{array}$ & $\begin{array}{l}20+ \\
\text { organ- } \\
\text { isms }\end{array}$ & $\begin{array}{l}0 \text { to } 4 \\
\text { organ- } \\
\text { isms }\end{array}$ & $\begin{array}{l}5 \text { to } 19 \\
\text { organ- } \\
\text { igms }\end{array}$ & $\begin{array}{c}20+ \\
\text { organ- } \\
\text { isms }\end{array}$ \\
\hline 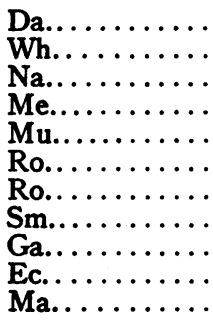 & $\begin{array}{r}0 \\
0 \\
10 \\
0 \\
0 \\
0 \\
0 \\
0 \\
0 \\
0 \\
0\end{array}$ & $\begin{array}{r}19 \\
6 \\
15 \\
7 \\
5 \\
2 \\
0 \\
1 \\
0 \\
11 \\
1\end{array}$ & $\begin{array}{r}6 \\
19 \\
0 \\
18 \\
20 \\
23 \\
25 \\
24 \\
25 \\
14 \\
24\end{array}$ & $\begin{array}{r}7 \\
1 \\
23 \\
6 \\
0 \\
0 \\
0 \\
0 \\
4 \\
2 \\
0\end{array}$ & $\begin{array}{r}17 \\
16 \\
2 \\
10 \\
19 \\
9 \\
7 \\
8 \\
17 \\
14 \\
14\end{array}$ & $\begin{array}{r}1 \\
8 \\
0 \\
9 \\
6 \\
16 \\
18 \\
17 \\
4 \\
9 \\
11\end{array}$ \\
\hline Average & 0.9 & 6.1 & 18 & 4 & 12 & 9 \\
\hline
\end{tabular}

that a freshly diluted Giemsa stain, as recommended by Singer-Brooks and Miller (15), was superior to the Wright's stain used by Bradford and Slavin for the blood films, and we therefore employed it in the present work.

The procedure described above was applied to the mother's blood just before she received her first inoculation of pertussis vaccine and again within the first few days after delivery. The blood of the newborn was tested simultaneously with the second determination on the mother's blood. The majority of newborns were tested within the first few days after birth. Five were tested before the first period of nursing and again at the end of the first week of life in an effort to determine the effect of colostrum. The controls consisted of mothers and their newborns who were in the hospital at the same time. An attempt was made to select the controls so that half of the mothers had had pertussis and half 
were reasonably sure that they had not. Aside from this consideration, they were picked at random. To insure uniformity, all blood samples were examined by one person (B. S.). As an additional precaution during the latter two-thirds of this work, the identity of each subject tested was withheld from the examiner until after the opsono-cytophagic reaction of the blood had been determined.

\section{RESULTS}

Complete observations on mother and newborn were obtained for 28 of the immunized mothers and 22 of the control mothers. It seemed de- sirable to place them in four separate groups, as shown in Figure 1 and by Tables I to IV, depending on whether or not the mother had had pertussis and whether or not she was immunized. It was found, as a survey of these tables shows, that in 84 per cent of the 128 individual opsonocytophagic tests performed, all the leukocytes counted contained at least 5 organisms. It seemed, therefore, that as a fair basis for comparison of the tests one might use the number of leukocytes which showed marked phagocytosis (i.e., contained 20 +organisms) to express the phagocytic power of each blood sample tested. This number is designated as the opsono-cyto-

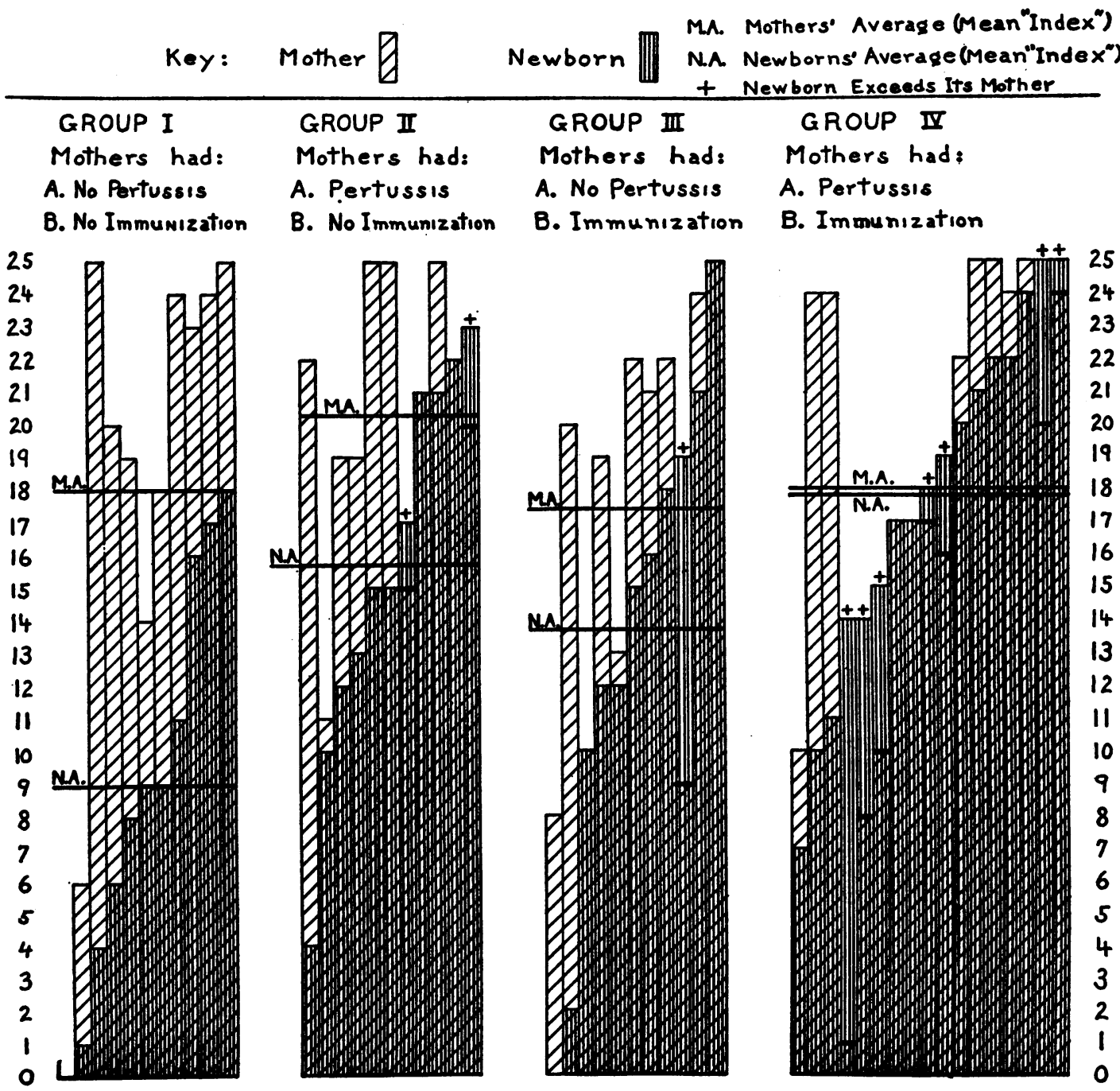

Fig. 1. Opsono-cytophagic “Index" of Blood for H. pertussis. Number of Leukocytes Showing Marked Phagocytosis 
TABLE II

The opsono-cytophagic reaction of the blood of mothers and newborns when the mother had a history of previous pertussis but no immunization during pregnancy

\begin{tabular}{|c|c|c|c|c|c|c|}
\hline \multirow{3}{*}{ Family name } & \multicolumn{3}{|c|}{ Mothers } & \multicolumn{3}{|c|}{ Newborns } \\
\hline & \multicolumn{3}{|c|}{$\begin{array}{l}\text { Distribution of cells ac- } \\
\text { cording to number of } \\
\text { organisms phagocytosed }\end{array}$} & \multicolumn{3}{|c|}{$\begin{array}{l}\text { Distribution of cells ac- } \\
\text { cording to number of } \\
\text { organisms phagocytoeed }\end{array}$} \\
\hline & $\begin{array}{l}0 \text { to } 4 \\
\text { organ- } \\
\text { isms }\end{array}$ & $\begin{array}{c}5 \text { to } 19 \\
\text { organ- } \\
\text { isms }\end{array}$ & $\begin{array}{c}20+ \\
\text { organ- } \\
\text { isms }\end{array}$ & $\begin{array}{c}0 \text { to } 4 \\
\text { organ- } \\
\text { isms }\end{array}$ & $\begin{array}{l}5 \text { to } 19 \\
\text { organ- } \\
\text { isms }\end{array}$ & 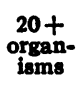 \\
\hline 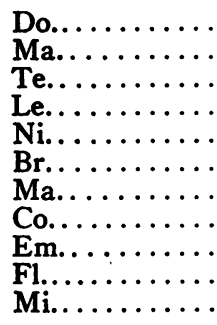 & $\begin{array}{l}0 \\
0 \\
0 \\
0 \\
0 \\
0 \\
0 \\
0 \\
0 \\
0 \\
0\end{array}$ & $\begin{array}{r}6 \\
5 \\
4 \\
14 \\
3 \\
0 \\
0 \\
0 \\
10 \\
6 \\
3\end{array}$ & $\begin{array}{l}19 \\
20 \\
21 \\
11 \\
22 \\
25 \\
25 \\
25 \\
15 \\
19 \\
22\end{array}$ & $\begin{array}{l}0 \\
1 \\
0 \\
0 \\
0 \\
0 \\
0 \\
1 \\
0 \\
2 \\
2\end{array}$ & $\begin{array}{r}12 \\
1 \\
4 \\
15 \\
3 \\
4 \\
10 \\
9 \\
8 \\
11 \\
19\end{array}$ & $\begin{array}{r}13 \\
23 \\
21 \\
10 \\
22 \\
21 \\
15 \\
15 \\
17 \\
12 \\
4\end{array}$ \\
\hline Average & 0 & 4.6 & 20.4 & 0.5 & 8.7 & 15.7 \\
\hline
\end{tabular}

phagic "index" in the present paper. It should not be confused with the term as used by other authors. A composite picture of the opsono-cytophagic " index" of the majority of blood samples tested is shown in Figure 1. Each column represents a mother and her infant whose "indices" have been superimposed. For the sake of uni- formity, the value for each immunized mother (Groups III and IV) represents the opsono-cytophagic reaction of her blood before she received vaccine. In most instances it will be noted that the "index" for the mother exceeds that of the respective infant, but in several cases this value for the rewborn is higher than its mother's. The columns representing these exceptions are marked at the top by a plus sign. They occur most frequently in Group IV where they comprise onethird of the columns. The means of the "indices" for the mothers and the newborns of each group are shown by heavy horizontal bars, marked M.A. and N.A., respectively. The numerical values for these mearis are shown in Table $V$, which also contains the standard deviation and the probable error of each.

Because the separation of the subjects into the four groups makes the number in each rather small, combinations of the mean "indices" of the groups were used. This was done in an effort to increase the amount of data which could be used to demonistrate the effect of either the immunization (Group I plus Group II vs. Group III plus Group IV) or previous pertussis in the mother (Group I plus Group III vs. Group II plus Group IV). The average values for the mean "indices" in the combinations mentioned

TABLE III

The opsono-cytophagic reaction of the blood of mothers and newborns when the mothers had no history of pertussis but were immunised with a pertussis vaccine during pregnancy

\begin{tabular}{|c|c|c|c|c|c|c|c|c|c|c|c|}
\hline \multirow{3}{*}{ Family name } & \multicolumn{3}{|c|}{$\begin{array}{l}\text { Mothers } \\
\text { Before immunization }\end{array}$} & \multirow{3}{*}{$\begin{array}{c}\text { Total } \\
\text { vaccine }\end{array}$} & \multirow{3}{*}{$\begin{array}{l}\text { Number } \\
\text { of injec- } \\
\text { tions }\end{array}$} & \multirow{2}{*}{\multicolumn{3}{|c|}{$\begin{array}{c}\text { Mothers } \\
\text { After immunization } \\
\begin{array}{c}\text { Distribution of cells according } \\
\text { to number of organisms } \\
\text { phagocytosed }\end{array}\end{array}$}} & \multicolumn{3}{|c|}{ Newborns } \\
\hline & \multicolumn{3}{|c|}{$\begin{array}{c}\text { Distribution of cells according } \\
\text { to number of organisms } \\
\text { phagocytosed }\end{array}$} & & & & & & \multicolumn{3}{|c|}{$\begin{array}{c}\text { Distribution of cells according } \\
\text { to number of organisms } \\
\text { phagocytosed }\end{array}$} \\
\hline & $\begin{array}{l}0 \text { to } 4 \\
\text { organ- } \\
\text { isms }\end{array}$ & $\begin{array}{l}5 \text { to } 19 \\
\text { organ- } \\
\text { isms }\end{array}$ & $\underset{\substack{\text { organ- } \\
\text { isms }}}{20+}$ & & & $\begin{array}{l}0 \text { to } 4 \\
\text { organ- } \\
\text { isms }\end{array}$ & $\begin{array}{l}5 \text { to } 19 \\
\text { organ- } \\
\text { isms }\end{array}$ & $\underset{\substack{20+\\
\text { organ- } \\
\text { isms }}}{20+}$ & $\begin{array}{l}0 \text { to } 4 \\
\text { organ- } \\
\text { isms }\end{array}$ & $\begin{array}{l}5 \text { to } 19 \\
\text { organ- } \\
\text { isms }\end{array}$ & $\begin{array}{l}20+ \\
\text { organ- } \\
\text { isms }\end{array}$ \\
\hline 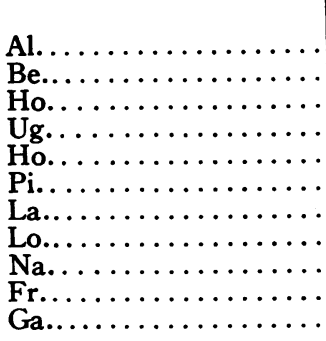 & $\begin{array}{l}\mathbf{0} \\
\mathbf{0} \\
\mathbf{0} \\
\mathbf{0} \\
\mathbf{0} \\
\mathbf{0} \\
\mathbf{0} \\
\mathbf{0} \\
\mathbf{0} \\
\mathbf{0} \\
\mathbf{0}\end{array}$ & $\begin{array}{r}13 \\
3 \\
16 \\
6 \\
17 \\
5 \\
4 \\
3 \\
15 \\
0 \\
1\end{array}$ & $\begin{array}{r}12 \\
22 \\
9 \\
19 \\
8 \\
20 \\
21 \\
22 \\
10 \\
25 \\
24\end{array}$ & $\begin{array}{l}c c . \\
1.5 \\
1.5 \\
1.5 \\
2.0 \\
1.5 \\
1.0 \\
3.5 \\
1.0 \\
1.5 \\
2.5 \\
2.0\end{array}$ & $\begin{array}{l}2 \\
2 \\
3 \\
3 \\
2 \\
2 \\
4 \\
2 \\
2 \\
3 \\
3\end{array}$ & $\begin{array}{l}\mathbf{0} \\
\mathbf{0} \\
\mathbf{0} \\
\mathbf{0} \\
\mathbf{0} \\
\mathbf{0} \\
\mathbf{0} \\
\mathbf{0} \\
\mathbf{0} \\
\mathbf{0} \\
\mathbf{0}\end{array}$ & $\begin{array}{r}3 \\
3 \\
15 \\
8 \\
9 \\
5 \\
9 \\
8 \\
14 \\
0 \\
0\end{array}$ & $\begin{array}{l}22 \\
22 \\
10 \\
17 \\
16 \\
20 \\
16 \\
17 \\
11 \\
25 \\
25\end{array}$ & $\begin{array}{r}0 \\
0 \\
0 \\
0 \\
7 \\
14 \\
0 \\
4 \\
1 \\
0 \\
0\end{array}$ & $\begin{array}{r}12 \\
7 \\
6 \\
13 \\
18 \\
9 \\
9 \\
6 \\
14 \\
0 \\
4\end{array}$ & $\begin{array}{r}13 \\
18 \\
19 \\
12 \\
0 \\
2 \\
16 \\
15 \\
10 \\
25 \\
21\end{array}$ \\
\hline Average ............. & $\mathbf{0}$ & 7.6 & 17.4 & 1.8 & 2.5 & $\mathbf{0}$ & 6.7 & 18.3 & 2.4 & 8.9 & 13.7 \\
\hline
\end{tabular}


TABLE IV

The opsono-cytophagic reaction of the blood of mothers and newborns when the mothers had a history of pertussis and also were immunised with a pertussis vaccine during pregnancy

\begin{tabular}{|c|c|c|c|c|c|c|c|c|c|c|c|}
\hline \multirow{3}{*}{ Family name } & \multicolumn{3}{|c|}{$\begin{array}{l}\text { Mothers } \\
\text { Before immunization }\end{array}$} & \multirow{3}{*}{$\begin{array}{c}\text { Total } \\
\text { vaccine }\end{array}$} & \multirow{3}{*}{$\begin{array}{l}\text { Number } \\
\text { of injec- } \\
\text { tions }\end{array}$} & \multirow{2}{*}{\multicolumn{3}{|c|}{$\frac{c}{\text { Mothers }} \begin{array}{c}\text { After immunization } \\
\begin{array}{c}\text { Distribution of cells according } \\
\text { to number of organisms } \\
\text { phagocytosed }\end{array}\end{array}$}} & \multicolumn{3}{|c|}{ Newborns } \\
\hline & \multicolumn{3}{|c|}{$\begin{array}{c}\text { Distribution of cells according } \\
\text { to number of organisms } \\
\text { phagocytosed }\end{array}$} & & & & & & \multicolumn{3}{|c|}{$\begin{array}{c}\text { Distribution of cells according } \\
\text { to number of organisms } \\
\text { phagocytosed }\end{array}$} \\
\hline & $\begin{array}{l}0 \text { to } 4 \\
\text { organ- } \\
\text { isms }\end{array}$ & $\begin{array}{l}5 \text { to } 19 \\
\text { organ- } \\
\text { isms }\end{array}$ & $\begin{array}{c}20+ \\
\text { organ- } \\
\text { isms }\end{array}$ & & & $\begin{array}{l}0 \text { to } 4 \\
\text { organ- } \\
\text { isms }\end{array}$ & $\begin{array}{l}5 \text { to } 19 \\
\text { organ- } \\
\text { ism8 }\end{array}$ & $\underset{\text { organ- }}{20+}$ & $\begin{array}{l}0 \text { to } 4 \\
\text { organ- } \\
\text { isms }\end{array}$ & $\begin{array}{l}5 \text { to } 19 \\
\text { organ- } \\
\text { isms }\end{array}$ & $\underset{\substack{20+\\
\text { organ- } \\
\text { isms }}}{20+}$ \\
\hline 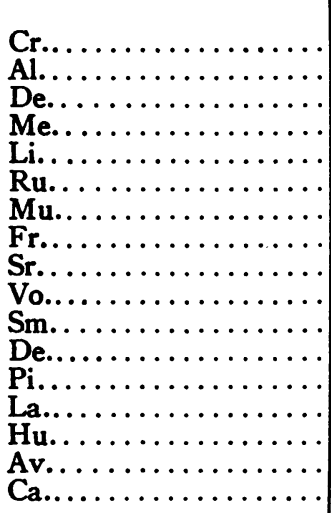 & $\begin{array}{l}0 \\
0 \\
1 \\
0 \\
0 \\
0 \\
0 \\
0 \\
0 \\
0 \\
0 \\
0 \\
0 \\
0 \\
0 \\
0 \\
0\end{array}$ & $\begin{array}{r}9 \\
1 \\
7 \\
2 \\
8 \\
24 \\
15 \\
15 \\
17 \\
8 \\
5 \\
0 \\
3 \\
0 \\
0 \\
1 \\
3\end{array}$ & $\begin{array}{r}16 \\
24 \\
17 \\
23 \\
17 \\
1 \\
10 \\
10 \\
8 \\
17 \\
20 \\
25 \\
22 \\
25 \\
25 \\
24 \\
22\end{array}$ & $\begin{array}{l}c c . \\
4.5 \\
2.0 \\
2.5 \\
3.0 \\
1.5 \\
2.5 \\
1.0 \\
1.0 \\
2.5 \\
1.5 \\
1.0 \\
2.0 \\
3.5 \\
3.0 \\
2.0 \\
2.0 \\
2.5\end{array}$ & $\begin{array}{l}5 \\
3 \\
5 \\
4 \\
3 \\
3 \\
2 \\
2 \\
3 \\
3 \\
2 \\
3 \\
4 \\
4 \\
3 \\
3 \\
3\end{array}$ & $\begin{array}{l}0 \\
0 \\
0 \\
0 \\
0 \\
0 \\
0 \\
1 \\
0 \\
0 \\
0 \\
0 \\
0 \\
0 \\
0 \\
0 \\
0\end{array}$ & $\begin{array}{r}10 \\
1 \\
4 \\
0 \\
4 \\
21 \\
15 \\
12 \\
1 \\
1 \\
0 \\
5 \\
3 \\
2 \\
1 \\
2 \\
0\end{array}$ & $\begin{array}{r}15 \\
24 \\
21 \\
25 \\
21 \\
4 \\
10 \\
12 \\
24 \\
24 \\
25 \\
20 \\
22 \\
23 \\
24 \\
23 \\
25\end{array}$ & $\begin{array}{l}0 \\
0 \\
0 \\
0 \\
0 \\
1 \\
1 \\
0 \\
0 \\
1 \\
0 \\
0 \\
0 \\
0 \\
0 \\
0 \\
1\end{array}$ & $\begin{array}{r}6 \\
0 \\
8 \\
15 \\
7 \\
10 \\
17 \\
10 \\
11 \\
7 \\
0 \\
1 \\
1 \\
4 \\
3 \\
14 \\
4\end{array}$ & $\begin{array}{r}19 \\
25 \\
17 \\
10 \\
18 \\
14 \\
7 \\
15 \\
14 \\
17 \\
25 \\
24 \\
24 \\
21 \\
22 \\
11 \\
20\end{array}$ \\
\hline Average ............ & 0 & 7 & 18 & 2.2 & 3 & 0 & 4.8 & 20.2 & 0.2 & 7 & 17.8 \\
\hline
\end{tabular}

TABLE V

A summary of the mean opsono-cytophagic "indices" (M) of both the mothers and the newborns in Groups I to $I V$, with the standard deviation $(S . D$.) and the probable error of the mean (P.E. M.) of each

\begin{tabular}{|c|c|c|c|c|c|c|c|c|c|c|}
\hline \multirow{3}{*}{ Group } & \multirow{3}{*}{$\begin{array}{c}\text { Num- } \\
\text { ber } \\
\text { of } \\
\text { cafess }\end{array}$} & \multicolumn{6}{|c|}{ Mothers } & \multicolumn{3}{|c|}{ Newborns } \\
\hline & & \multicolumn{3}{|c|}{$\begin{array}{c}\text { Before } \\
\text { immunisation }\end{array}$} & \multicolumn{3}{|c|}{$\begin{array}{c}\text { After } \\
\text { immunisation }\end{array}$} & \multirow{2}{*}{ M. } & \multirow{2}{*}{ S.D. } & \multirow{2}{*}{ P.E.M. } \\
\hline & & M. & S.D. & P.E.M. & M. & S.D. & P.E.M. & & & \\
\hline & $\begin{array}{l}11 \\
11 \\
11 \\
17\end{array}$ & $\begin{array}{l}18 \\
20.4 \\
17.4 \\
18\end{array}$ & $\begin{array}{l}.89 \\
4.13 \\
6.46 \\
6.86\end{array}$ & $\begin{array}{l}1.689 \\
0.696 \\
1.38 \\
1.16\end{array}$ & $\begin{array}{l}18.3 \\
20.2\end{array}$ & \begin{tabular}{|l|}
4.82 \\
6.03
\end{tabular} & $\begin{array}{l}1.025 \\
1.017\end{array}$ & $\begin{array}{r}9.0 \\
15.7 \\
13.7 \\
17.8\end{array}$ & $\begin{array}{l}4.71 \\
5.61 \\
7.26 \\
5.51\end{array}$ & $\begin{array}{l}.005 \\
0.918 \\
1.55 \\
0.930\end{array}$ \\
\hline
\end{tabular}

above are shown in Table VI. A study of this table shows that the mother's previous pertussis and the artificial immunization each produce a statistically significant effect on the opsono-cytophagic "index" of the newborn's blood. It is obvious from Figure 1 that when these factors are combined (subjects of Group IV), a summation-effect is obtained which raises the mean "index" of the newborn to practically the same value as the mean "index" of the mother.

It is also apparent in Tables $\mathrm{V}$ and VI that neither of these two factors materially alters the opsono-cytophagic "index" of the mother. In fact, the mean "index" of the 28 immunized mothers was changed so little by this procedure that the values before and after serve as a check on the reliability of the method for testing. For this reason, in Figure 1 we feel justified in including only the "index" of blood samples taken from these mothers (Groups III and IV) before immunization was carried out.

'It is, of course, possible that the phagocytic power (as an expression of antibody titer) of each mother's blood exerts an influence on this capacity of her infant's blood, irrespective of whether she had previous pertussis or whether she was immunized. In other words, one might expect to find a certain basic degree of correlation between mother and offspring. The possible existence of this relationship was tested by means of a correlation graph, as shown in Figure 2. The data used in constructing this graph were the opsono-cytophagic "indices" of the 22 control (non-immunized) mothers and newborns in our own group of subjects plus a group of 22 
TABLE VI

Various combinations of the data of Table $V$ used to increase the number of cases influenced by either the history of previous pertussis for the mother or immunisation of the mother during pregnancy

\begin{tabular}{|c|c|c|c|c|c|c|c|c|}
\hline \multirow{3}{*}{ Groups } & \multirow{3}{*}{$\begin{array}{c}\text { Number } \\
\text { of } \\
\text { cases }\end{array}$} & \multirow{3}{*}{ Qualification } & \multicolumn{2}{|c|}{ Mothers } & \multicolumn{3}{|c|}{ Newborns } & \multirow{3}{*}{$\begin{array}{l}\text { Difference } \\
\text { of means }\end{array}$} \\
\hline & & & Before immunization & After immunization & \multirow{2}{*}{ M. } & \multirow{2}{*}{ S.D. } & \multirow{2}{*}{ P.E.M. } & \\
\hline & & & M. & M. & & & & \\
\hline $\begin{array}{l}\text { I and II... } \\
\text { III and IV. }\end{array}$ & $\begin{array}{l}22 \\
28\end{array}$ & $\begin{array}{l}\text { Mother not immunized } \\
\text { Mother immunized }\end{array}$ & $\begin{array}{l}19.2^{*} \\
17.7^{*}\end{array}$ & $19.4^{*}$ & \begin{tabular}{|l|}
12.4 \\
16.2
\end{tabular} & $\begin{array}{l}6.34 \\
6.50 \\
\end{array}$ & $\begin{array}{l}.935 \\
.845\end{array}$ & $\begin{array}{l}3.8 \pm 1.23 \\
\text { significant }\end{array}$ \\
\hline $\begin{array}{l}\text { I and III.. } \\
\text { II and IV.. }\end{array}$ & $\begin{array}{l}22 \\
28\end{array}$ & $\begin{array}{l}\text { No pertussis for mother } \\
\text { Mother had pertussis }\end{array}$ & $\begin{array}{l}17.7^{*} \\
18.9^{*}\end{array}$ & & \begin{tabular}{|l|}
11.4 \\
17
\end{tabular} & $\begin{array}{l}6.48 \\
5.64\end{array}$ & $\begin{array}{l}.915 \\
.583\end{array}$ & $\begin{array}{l}5.6 \pm 1.21 \\
\text { significant }\end{array}$ \\
\hline
\end{tabular}

* Means are so close that calculation of S. D. and P. E. M. is not worth while.

comparable pairs of mother and offspring taken include them. Of the 44 mothers used for this from the previously published results of Brad- purpose, 25 had had pertussis and 19 had not. ford and Slavin (10). Since this latter group Although it does not appear striking to the eye, was tested in the same manner by the same person a statistical analysis of the data comprising this who performed our tests, it seemed proper to graph shows a significant correlation to be present

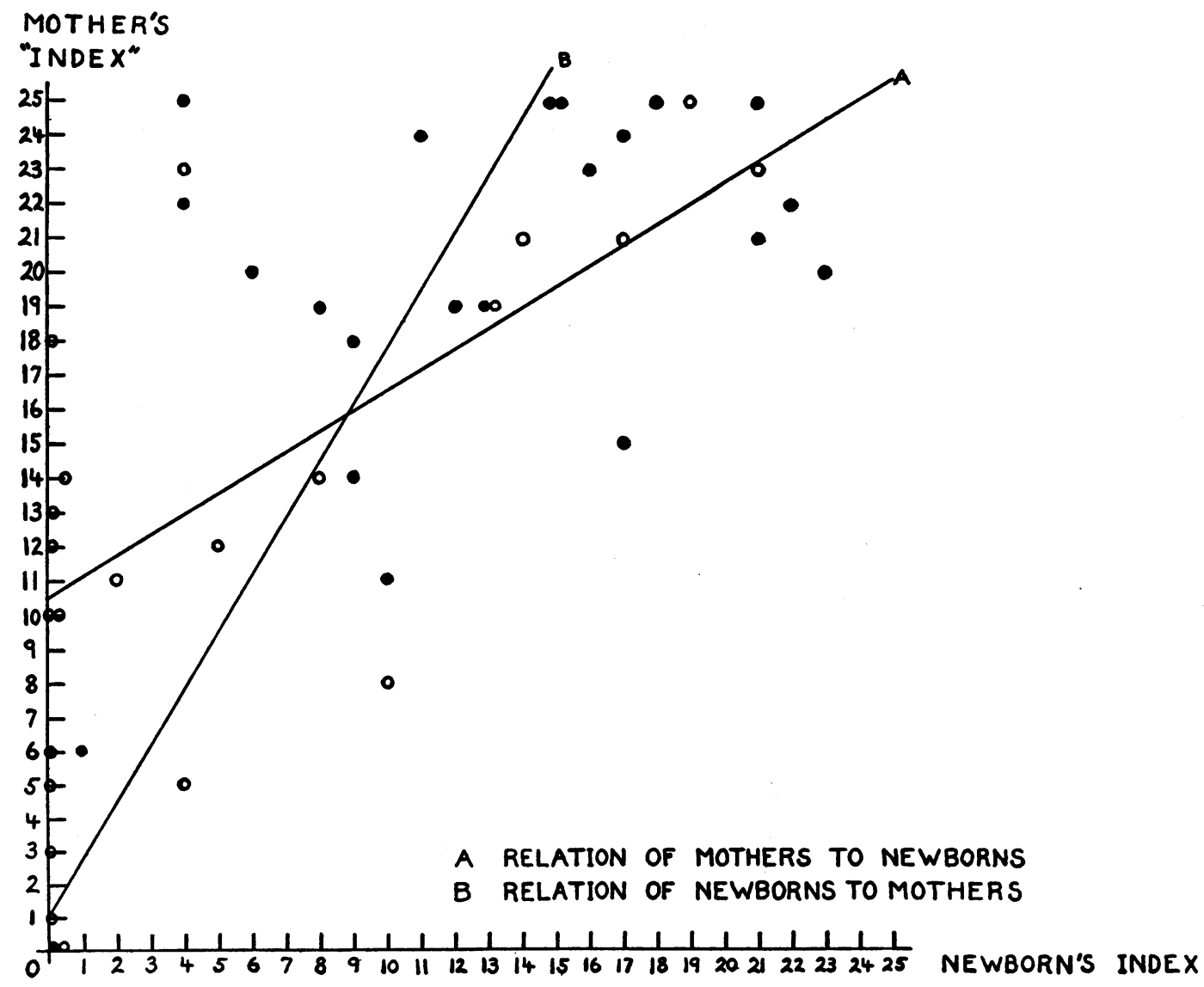

Fig. 2. Correlation Graph for the Opsono-cytophagic "Index" of Mother and Newborn

- Series I ( 22 cases)

O Series II ( 22 cases) 
between the "indices" of the mother and of the newborn.

In Table VII we have arranged the results of the opsono-cytophagic reaction of the bloods of 5 newborns tested before the first period of nursing and again at the end of the first week of life. It is clear that there has been practically no change in this reaction, certainly no increase in phagocytic capacity, after receiving colostrum.

TABLE VII

The effect of colostrum on the opsono-cytophagic reaction of the newborn's blood

\begin{tabular}{|c|c|c|c|c|c|c|}
\hline \multirow{3}{*}{ Family name } & \multirow{2}{*}{\multicolumn{3}{|c|}{\begin{tabular}{|l}
\multicolumn{1}{c}{$\begin{array}{c}\text { Newborn before } \\
\text { nursing }\end{array}$} \\
$\begin{array}{l}\text { Distribution of cells ac- } \\
\text { cording to number of } \\
\text { organisms phagocytosed }\end{array}$
\end{tabular}}} & \multirow{2}{*}{\multicolumn{3}{|c|}{$\begin{array}{c}\text { Newborn after } \\
\text { nursing one week }\end{array}$}} \\
\hline & & & & & & \\
\hline & $\begin{array}{l}0 \text { to } 4 \\
\text { organ- } \\
\text { isms }\end{array}$ & $\begin{array}{l}5 \text { to } 19 \\
\text { organ- } \\
\text { isms }\end{array}$ & $\underset{\substack{20+\\
\text { isms }}}{20+}$ & $\begin{array}{l}0 \text { to } 4 \\
\text { organ- } \\
\text { isms }\end{array}$ & $\begin{array}{l}5 \text { to } 19 \\
\text { organ- } \\
\text { isms }\end{array}$ & $\underset{\substack{20+\\
\text { organ- } \\
\text { isms }}}{ }$ \\
\hline 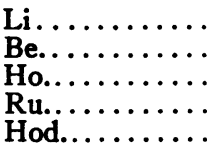 & $\begin{array}{l}0 \\
0 \\
0 \\
1 \\
7\end{array}$ & $\begin{array}{r}7 \\
7 \\
6 \\
10 \\
18\end{array}$ & $\begin{array}{r}18 \\
18 \\
19 \\
14 \\
0\end{array}$ & $\begin{array}{r}0 \\
0 \\
0 \\
2 \\
16\end{array}$ & $\begin{array}{r}7 \\
8 \\
5 \\
20 \\
9\end{array}$ & $\begin{array}{r}18 \\
17 \\
20 \\
3 \\
0\end{array}$ \\
\hline
\end{tabular}

\section{DISCUSSION}

Bradford and Slavin (10) concluded from their studies of the opsono-cytophagic reaction of the blood of mothers and newborns that (1) there was a certain degree of correlation between their respective titers, and (2) that the titer of both mother and newborn was higher when the former had had pertussis. Our results are in accord with the first of these conclusions and with a part of the second, namely, that the mother's previous pertussis exerts a definite influence on the opsonocytophagic reaction of the newborn's blood. We are not able to show that it affects the titer of the mother's blood to any significant degree. We are unable to explain this discrepancy.

Our results correspond with what one would expect on the basis of the studies of BeninholdtThomsen (8), demonstrating the trans-placental passage of complement-fixing antibodies from rabbits immunized with a pertussis vaccine to their offspring. They are not in accord with the conclusion of Kendrick, Gibbs, and Sprick (16) that the blood of rewborn infants shows a nega- tive or very weak opsono-cytophagic reaction regardless of the reaction of the mother.

Our results suggest that at least three factors may exert an appreciable influence on the phagocytic capacity of the blood leukocytes of the newborn infant for $H$. pertussis: (1) The phagocytic power of the mother's blood; (2) previous pertussis in the mother; and (3) artificial immunization of the mother with pertussis vaccine during the latter part of pregnancy. There may be many additional factors. By a satisfactory grouping of our subjects we can study the effect of the second and third factors independently of each other, but the effect of the first factor obviously cannot be eliminated by this means. Therefore, it seems best to consider the phagocytic power of the newborn's blood in terms of the same capacity of the mother's blood. If we apply this line of reasoning to Figure 1, the mean "index" of the newborns in Group $I$ is 50 per cent of that of the respective mothers while in each of Groups II and III it is approximately 75 per cent and in Group IV it has risen to 100 per cent (i.e., equal to that of the respective group of mothers). Orie might be justified in concluding that either previous pertussis in the mother or active immunization during pregnancy increases this phagocytic capacity of the newborn to a similar degree, and both factors exert a summationeffect which puts the newborn at the same level as the mother.

Three important questions arise: (1) Is the phagocytic reaction a true measure of the specific opsonizing antibodies for $H$. pertussis in the newborns studied? (2) How long during early infancy will it remain unchanged? (3) Is there any correlation between this capacity and resistance to pertussis? In answer to the first question Bradford and Slavin (10), Kendrick et al. (16) and Singer-Brooks and Miller (15) have shown that the phagocytic capacity increases in the blood of patients during the latter part of pertussis and during convalescence. Furthermore, Bradford et al. (17) have shown that it increases in infants and children following the injection of anti-pertussis serum (human or rabbit), and Kendrick et al. (16) have found that it is increased in human beings by active immunization with a pertussis vaccine. However, SingerBrooks and Miller (15) have shown it to be in- 
creased in subjects after immunization with a nonspecific, "mixed respiratory" vaccine, and they present a detailed discussion of some of the nonspecific factors which may influence phagocytosis of organisms by blood leukocytes.

We are unable to give a definite answer to either the second or the third questions because of the small number of patients in our study, and because we were unable to get a sufficient number of subsequent opsono-cytophagic tests on our infants during their first year of life to justify any conclusions. However, it occurred to us that some clinical evidence could be obtained from the hospital records which might furnish a partial answer to both these questions. Thus, if this laboratory test be a measure of resistance to pertussis, during the first half-year of life infants whose mothers had had pertussis might be expected to have milder cases of the disease than infants whose mothers had not had this infection. After the age of 6 months this effect might be expected to disappear as the titer of "inherited" antibodies decreased in the blood of the child, provided one can reason by analogy from other infectious diseases, such as diphtheria. One simple way to test this theory is to note the effect of the mother's previous pertussis on the infant mortality rate from this disease. Accordingly, the family histories of $\mathbf{4 5}$ infants known to have died from pertussis in this hospital were studied. Definite information could be obtained in only 31 of these, but in the cases of 18 infants who died before the age of 6 months, the mothers of only 5 had had previous pertussis, while in the group of 13 infants who died after the age of 6 months, 7 of the mothers had had pertussis and 6 had no knowledge of it. In other words, the findings seemed to bear out the argument advanced above. The results are strengthened by the fact that the observations were made on people of the same geographical and economic position as that group of mothers who were vaccinated in our own studies, and in this latter group (selected at random) more than half of the mothers had had pertussis. Only in that group of mothers whose infants died from pertussis under the age of 6 months do we find any appreciable decrease in the incidence of this disease. The series of cases is too small to permit definite conclusions, but the evidence is in agreement with the contention that resistance to pertussis in infancy may be associated with the phagocytic reaction of the blood for $H$. pertussis.

It seemed surprising that the mean "index" of the immunized mothers did not increase as a result of this procedure. We have no adequate explanation for this finding, except that this value was in general quite high before immunization was started.

In the five infants tested before and after nursing, the results suggest that the colostrum has no effect upon the phagocytic reaction of the newborn. However, we do not feel justified in drawing conclusions from such a limited experience. Possibly the interval between the two tests should be lengthened.

\section{SUM MARY}

1. The opsono-cytophagic reaction of the blood of the newborn infant for $H$. pertussis is significantly influenced by at least three factors; (a) the phagocytic capacity of the mother's blood; (b) previous pertussis in the mother; and (c) artificial immunization of the mother with pertussis vaccine during the latter part of pregnancy.

2. Certain evidence from hospital case records suggests that this phagocytic capacity may be regarded as a measure of resistance to pertussis.

3. Neither the previous disease nor artificial immunization with a pertussis vaccine during pregnancy exerted any significant influence on the opsono-cytophagic reaction of the mother's blood for $H$. pertussis.

4. In a few infants tested before and after nursing, no apparent increase in the phagocytic capacity of blood for $H$. pertussis was produced by the colostrum obtained during the first week of life.

We are greatly indebted to Dr. S. W. Clausen for his statistical analysis of the data, and to Dr. Karl Wilson for permission to use the patients on the Obstetrical Service of the Strong Memorial and Rochester Municipal Hospitals. Dr. G. P. Berry assisted in the preparation of this report with many valuable suggestions.

\section{BIBLIOGRAPHY}

1. McKhann, C. F., and Chu, F. T., Antibodies in placental extracts. J. Infect. Dis., 1933, 52, 268.

2. Ratner, B., Jackson, H. C., and Gruehl, H. L., Transmission of protein hypersensitiveness from mother 
to offspring. I. Critique of placental permeability. J. Immunol., 1927, 14, 249.

3. Aycock, W. L., and Kramer, S. D., Immunity to poliomyelitis in mothers and the newborn as shown by the neutralization test. J. Exper. Med., 1930, 52, 457.

4. Pfaundler, M., and Schlossmann, A., The Diseases of Infants and Children. Vol. III. (Translated by M. G. Peterman.) J. B. Lippincott Co., Philadelphia, 1935, 4th ed.

5. Griffith, J. P. C., and Mitchell, A. G., The Diseases of Infants and Children. W. B. Saunders Co., Philadelphia, 1937, new 2d ed.

6. Burckhardt, A. E., Zur intrauterinen Vaccination. Deutsches Archiv. f. klin. Med., 1879, 24, 506.

7. Polano, O., Der Antitoxinübergang von der Mutter auf das Kind. Ein Beitrag zur Physiologie der Placenta. Ztschr. f. Geburtsh. u. Gynäk., 1904, 53, 456.

8. Bennholdt-Thomsen, C., Das Verhalten eines gegen den Bordet-Gengou-Bacillus spezifischen Amboceptors bei Mutter und Kind. Ztschr. f. Kinderh., 1934-35, 57, 532.

9. Weichsel, M., and Douglas, H. S., Complement fixation tests in pertussis. J. Clin. Invest., 1937, 16, 15.
10. Bradford, W. L., and Slavin, B., The opsono-cytophagic reaction of the blood in pertussis. J. Clin. Invest., 1937, 16, 825.

11. Bradford, W. L., Use of convalescent blood in whooping cough, with a review of the literature. Am. J. Dis. Child., 1935, 50, 918.

12. Rodolfo, A., A study of the permeability of the placenta of the rabbit to antibodies. J. Exper. Zool., 1934, 68, 215.

13. Sauer, L. W., Immunization with bacillus pertussis vaccine. J. A. M. A., 1933, 101, 1449.

14. Huddleson, I. F., Johnson, H. W., and Hamann, E. E., A study of the opsono-cytophagic power of the blood and allergic skin reaction in Brucella infection and immunity in man. Am. J. Pub. Health, 1933, 23, 917.

15. Singer-Brooks, C., and Miller, J. J., Jr., The opsonocytophagic test in children with pertussis and in children vaccinated with $H$. pertussis antigens. J. Clin. Invest., 1937, 16, 749.

16. Kendrick, P., Gibbs, J., and Sprick, M., The opsonocytophagic test in the study of pertussis. J. Infect. Dis., 1937, 60, 302.

17. Bradford, W. L., Mikell, R., and Slavin, B., The effect of immune blood upon the opsono-cytophagic power of the blood in pertussis. J. Clin. Invest., 1937, 16, 829. 